\title{
$\mathrm{MPPT}$ 제어기능을 갖는 마이크로 빛에너지 하베스팅 회로
}

\section{( A Micro Solar Energy Harvesting Circuit with MPPT Control)}

\author{
윤 은 정*, 박 종 태**, 유 종 근** \\ ( Eun-Jung Yoon, Jong-Tae Park, and Chong-Gun Yu ${ }^{(0)}$ \\ 요 약
}

본 논문에서는 $0.5 \mathrm{~V}$ 이하의 낮은 전압을 출력하는 초소형 $\mathrm{PV}$ (photovoltaic) 셀을 이용한 MPPT(Maximum Power Point Tracking) 제어 기능을 갖는 마이크로 빛에너지 하베스팅 시스템을 제안한다. MPPT 제어는 PV 셀의 개방전압과 MPP(Maximum Power Point) 전압간의 비례관계를 이용하여, 파일럿(pilot) PV 셀로 하여금 주(main) PV 셀의 MPP를 실시간 추적할 수 있도록 설계하였다. 제안된 회로는 $0.18 \mathrm{um} \mathrm{CMOS}$ 공정으로 설계되었으며, 칩 면적은 부하단 전하펌프와 패드를 포함하여 900um×1370um 이다. 제작된 칩을 측정한 결과 설계된 회로가 빛 세기의 변화에 따른 MPP 전압 변화를 실시간 트래킹하는 것을 확인하였다. 또한 $\mathrm{MPPT}$ 제어기능을 적용했을 때 부하가 큰 경우에도 MPP 근처의 전압을 부하에 공급함으로써 MPPT 제어기능을 적용하지 않았을 때에 비해 더 많은 전력을 부하로 공급하는 것을 확인하였다. 기존의 마이크로 빛에너지 하베스팅 회로에 비해 제안된 회로는 제어 회로 구동을 위해 미리 충전된 배터리가 필요하지 않기 때문에 배터리를 사용하지 않는 초소형 자가발전 시스템에 적합하다.

\begin{abstract}
In this paper a micro solar energy harvesting system with MPPT(Maximum Power Point Tracking) control using a miniature PV(photovoltaic) cell of which the output is less than $0.5 \mathrm{~V}$ is proposed. The MPPT control is implemented using linear relationship between the open-circuit voltage of a PV cell and its MPP(Maximum Power Point) voltage such that a pilot PV cell can track the MPP of the main PV cell in real time. The proposed circuit is designed in 0.18um CMOS process. The designed chip area is $900 \mathrm{um} \times 1370 \mathrm{um}$ including a load charge pump and pads. Measured results show that the designed system can track the MPP voltage changes with variations of light intensity. The designed circuit with MPPT control delivers MPP voltages to load even though the load is heavy such that it can supply more power when the MPPT control is applied. The proposed circuit does not require any precharged battery resulting in more suitability for miniaturized self-powered systems compared to the existing works.
\end{abstract}

Keywords : Energy Harvesting, Solar Energy, Solar Cell, MPPT, Charge Pump

\section{I. 서 론}

최근 무선 네트워킹을 통해 사람과 사물간의 통신뿐 만 아니라 사물과 사물간의 통신까지 정보흐름의 영역 을 확대하기 위한 USN(Ubiquitous Sensor Network)

\footnotetext{
"학생회원, ** 평생회원, 인천대학교 전자공학과

(Dept. of Electronics Engineering, University of Incheon)

※ 이 논문은 2012년도 정부(교육과학기술부)의 재원으

로 한국연구재단의 기초연구사업 지원을 받아 수행

된 것임(2010-0021112). IDEC 지원에 의해서도 일 부 수행되었음
}

(c) Corresponding Author(E-mail: chong@incheon.ac.kr)

접수일자 2013년1월23일, 수정완료일 2013년5월14일
기술 개발이 활발히 진행되고 있다. USN 구현의 핵심 블록인 센서노드의 구동을 위해서는 센서노드 규격에 적합한 초소형, 초경량, 장수명성을 가지는 전원소자를 사용하여 완전히 독립된 자체 전원을 확보하는 것이 중 요하다. 센서노드의 경우에는 반영구적으로 일정 부위 에 부착되어 상시 모니터링 및 상호 통신기능을 수행하 는 장치이기 때문에 교체가 어려운 일차전지보다는 지 속적으로 사용 가능한 2차전지가 적합하다. 그러나 센 서노드는 보통의 경우 유선 충전이 불가능한 곳에 위치 하기 때문에 무선충전이나 자가발전(self-powered) 기 능이 필요하며, 자가발전 또는 배터리 대용으로 사용될 수 있는 기술이 에너지 하베스팅(energy harvesting) 
기술이다 ${ }^{[1 \sim 3]}$.

빛에너지는 태양, 조명등에서 가장 쉽게 얻을 수 있 는 에너지이며 상대적으로 변환 효율이 높기 때문에 오 래전부터 연구 개발이 진행되어 왔다. 빛에너지를 전기 에너지로 변환하기 위해서는 광전효과를 이용한 $\mathrm{PV}$ (photovoltaic) 셀이 필요하다. 초소형 빛 에너지 하 베스팅 시스템을 구현하기 위해서는 초소형 PV 셀이나 다른 회로와 함께 집적되는 ISC(integrated solar cell) 를 사용해야 한다. 그러나 초소형 PV 셀이나 ISC에서 출력되는 전압은 0.5 보다 작은 전압이기 때문에, 시스템 을 직접 구동할 수 없으며 전압을 키우기 위한 전압부 스터(voltage booster)가 필요하다.

$\mathrm{PV}$ 셀에서 얻을 수 있는 에너지의 양은 환경변화에 따라 변한다. 각 셀마다 최대 전력점 (MPP: Maximum Power Point)이 존재하며, 이 $\mathrm{MPP}$ 는 빛의 세기에 따라 변한다. PV셀로부터 최대 전력을 수확하기 위해서는 $\mathrm{PV}$ 셀이 항상 $\mathrm{MPP}$ 근처에서 동작하도록 하기 위한 MPPT(Maximum Power Point Tracking) 제어 기능이 필요하다. 초소형 $\mathrm{PV}$ 셀로부터 얻을 수 있는 전력은 수 십 $\mathrm{uW}$ 이하로 매우 작기 때문에, 초소형 에너지 하베스 팅 시스템의 경우 MPPT 기능은 더 필요할 수 있다. 따 라서, MPPT 기능을 구현하는데 소모되는 추가적인 전 력소모는 최소화하면서 PV 셀로부터 가능한 최대 전력 을 끄집어내는 것이 관건이다.

다양한 MPPT 방법들 ${ }^{[4]}$ 중에 hill-climbing 방법과 FOC(fractional open-circuit) 방법이 초소형 빛에너지 하베스팅 시스템에 주로 사용되어 왔다. Hill-climbing 방법은 $\mathrm{MPP}$ 에 도달할 때까지 전력변환기(power converter)의 스위칭 주파수나 듀티 싸이클(duty cycle) 을 지속적으로 변화시키는 반복탐색 방식이다. 기존의 hill-climbing 방식[9-11]에서는 순간 출력 전력을 계산 하기 위해 마이크로컨트롤러를 사용하였기 때문에, 초 소형 마이크로 에너지 하베스팅 시스템에는 적합하지 않다. 참고문헌 [8]에서는 마이크로컨트롤러 없이 전류 센서, $\mathrm{VCO}$, 컨트롤 로직 등만을 사용하여 hill-climbing 방법을 구현하여, 하드웨어 크기, 비용 및 전력소모를 줄였다. 하드웨어 비용 및 전력을 더욱 줄이기 위해, 참 고문헌 [7]에서는 polynomial $\mathrm{VCO}$ 만을 사용하여 MPPT 제어 기능을 구현할 수 있는 부궤한 제어루프 (negative-feedback control loop) 방식을 제안하였다. 그러나 이들 방식 ${ }^{[7 \sim 8]}$ 에서는 MPPT 제어 회로를 구동 하기 위해 미리 충전된 배터리 (precharged battery)가 필요하며, 따라서 배터리를 사용하지 않는 자가발전 시
스템에는 적합하지 않다.

$\mathrm{FOC}$ 방법은 $\mathrm{PV}$ 셀의 $\mathrm{MPP}$ 전압과 개방회로 전압 사이에는 선형적 관계가 존재하며, 비례상수는 거의 일 정한 값을 갖는다는 사실에 근거한다. 따라서, $\mathrm{PV}$ 셀을 주기적으로 부하로의 연결을 차단하여 개방회로 전압을 측정함으로써 MPP 전압을 쉽게 얻을 수 있다. 이 방법 은 hill-climbing 방법에서처럼 많은 계산을 요구하지는 않지만, 에너지 하베스팅 모드와 개방회로전압 감지 모 드의 반복 수행에 필요한 하드웨어 비용과 추가적인 전 력소모가 관건이 될 수 있다. 좀 더 적은 비용과 저전력 으로 $\mathrm{FOC}$ 방법을 구현하기 위해, 참고문헌 [6]에서 LRCM (Linear Reoriented Coordinate Method)을 제안 하였으며, 전력소모를 줄이기 위해 sub-threshold 및 floating-gate 설계 기법을 적용하였다. 주 에너지원으 로 ISC (CMOS photodiodes)를 사용하였으며, 제어회로 구동을 위해 보조 ISC (auxiliary photodiode array)를 사용하였다. 이 방법은 ISC를 사용하였기 때문에 초소 형 자가발전 시스템을 위한 에너지 하베스팅 회로로 적 합하다. 그러나 내부 회로 구동을 위해 $\mathrm{p}^{-\mathrm{diff} / \mathrm{n} \text {-well }}$ 다이오드의 직렬연결을 사용하였으며, 기판의 기생 다 이오드에서의 누설 전류를 반영하지 않은 상태로 모의 실험을 하였기 때문에 실제 구현시 문제가 될 수 있다.

본 논문에서는 배터리를 사용하지 않는 초소형 자가 발전 시스템을 위한 마이크로 빛 에너지 하베스팅 시스 템을 제안한다. 시스템의 크기를 최소화하기 위해 목표 로 하는 빛에너지 변환 소자는 초소형 $\mathrm{PV}$ 셀 $\left(0.14 \mathrm{~cm}^{2}\right)$ 또는 ISC이다. MPPT 구현에 $\mathrm{FOC}$ 방법을 이용하였으 나, 파일럿(pilot) $\mathrm{PV}$ 셀 $\left(0.07 \mathrm{~cm}^{2}\right)$ 을 이용하여 주(main) $\mathrm{PV}$ 셀의 개방회로 전압을 좀 더 간단히 예측하는 방법 을 사용하였다. MPPT 제어 회로의 구동은 간단한 승 압회로를 사용하여 주 PV 셀의 출력 전압을 승합하여 사용하기 때문에 미리 충전된 배터리가 필요하지 않다. 따라서, 제안된 회로는 배터리를 사용하지 않는 초소형 자가발전 시스템에 적합하다. 제안된 회로의 설계, 구현 및 측정결과에 대해 차례로 언급한다.

\section{II. 회로 설계}

그림 1 은 본 논문에서 제안하는 MPPT 제어기능을 갖는 마이크로 빛에너지 하베스팅 회로이다. 제안된 회 로는 주 $\mathrm{PV}$ 셀, $\mathrm{VB}$ (voltage booster), SEMC(Solar Energy MPPT Control) 회로, 전력 스위치(power switch) 그리고 부하단 전하폄프(charge pump)로 구성 


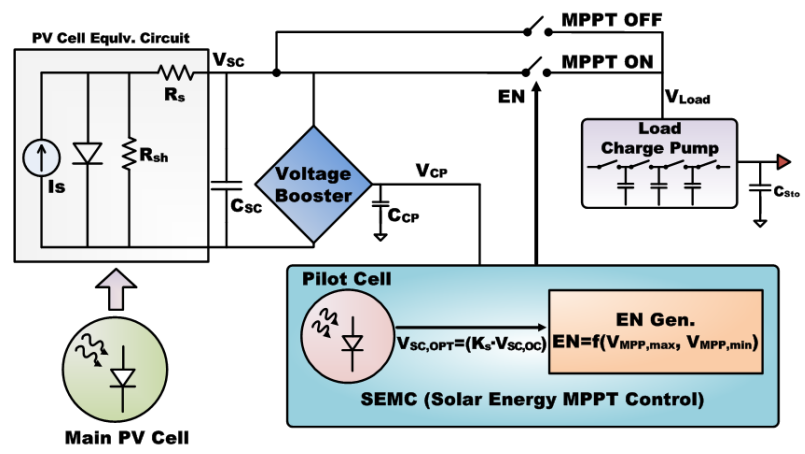

그림 1. 제안된 마이크로 빛에너지 하베스팅 회로

Fig. 1. Proposed micro-scale solar energy harvesting circuit.

되어있다. 솔라셀은 빛에너지를 전기에너지로 변환하는 역할을 하며, 본 논문에서 사용된 초소형 $\mathrm{PV}$ 셀의 출력 전압은 $0.5 \mathrm{~V}$ 보다 작기 때문에, $\mathrm{SEMC}$ 회로를 구동하기 에는 어려움이 있다. $\mathrm{VB}$ 는 $\mathrm{PV}$ 셀의 낮은 출력 전압을 $\mathrm{SEMC}$ 회로를 구동하는데 필요한 전압 (약 $1 \mathrm{~V}$ )으로 승 압하는 역할을 한다. $\mathrm{SEMC}$ 는 주 $\mathrm{PV}$ 셀과 부하단 사이 에 연결된 전력스위치(pMOS 트랜지스터)를 제어하여 주 $\mathrm{PV}$ 셀의 출력전압이 항상 $\mathrm{MPP}$ 근처에서 동작하도 록 하는 역할을 한다. 따라서 제안된 회로에서는 부하 단 전력공급의 듀티 싸이클 제어를 통해 MPPT기능을 수행한다. 부하단 전하펌프는 전력변환기 역할을 수행 한다.

\section{Photovoltaic (PV) cell}

시스템의 크기를 최소화하기 위해 본 논문에서 목표 로 하는 빛에너지 변환 소자는 초소형 PV 셀 또는 ISC 이다. 설계에 사용된 주 $\mathrm{PV}$ 셀은 그림 2 의 초소형 $\mathrm{SCPD}$ 소자 ${ }^{[12]}$ 로 $0.14 \mathrm{~cm}^{2}$ 의 면적과 $0.5 \mathrm{~V}$ 이하의 매우 낮은 출력전압 특성을 갖는다. 이 소자는 $\mathrm{CMOS}$ 공정 으로 집적화된 ISC와 유사한 크기와 출력전압 특성을 보인다.

그림 2의 $\mathrm{PV}$ 셀 등가회로를 모델링하기 위해 $\mathrm{SCPD}$

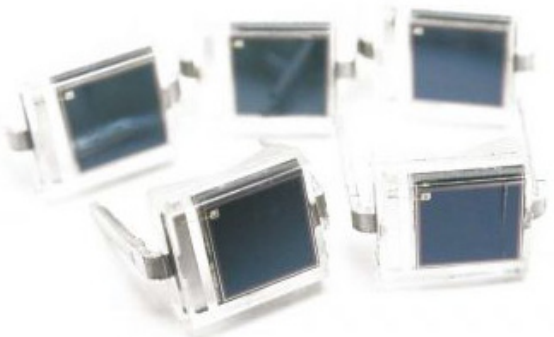

그림 2. 설계에 사용된 PV 셀 (SCPD)

Fig. 2. PV cell (SCPD) used in this design.

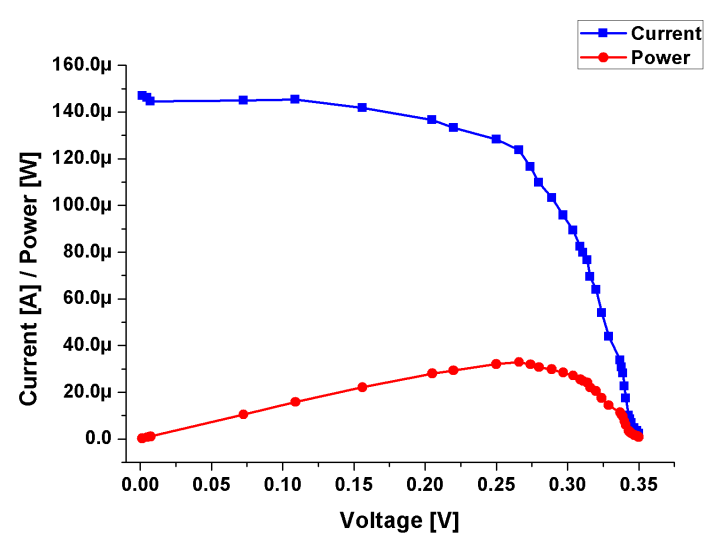

그림 3. 10klux에서 측정된 $\mathrm{PV}$ 셀의 $\mathrm{I} \mathrm{V} \& \mathrm{P}-\mathrm{V}$ 특성

Fig. 3. Measured $I-V \& P-V$ characteristics of the $P V$ cell at 10klux.

소자의 $\mathrm{I}-\mathrm{V}$ 와 $\mathrm{P}-\mathrm{V}$ 특성을 측정하였다. 그림 3 은 $10 \mathrm{klux}$ 의 빛 세기에서 측정한 $\mathrm{PV}$ 셀의 $\mathrm{I}-\mathrm{V}$ 와 $\mathrm{P}-\mathrm{V}$ 특 성곡선이다. 측정결과 개방회로전압 $\left(\mathrm{V}_{\mathrm{OC}}\right)$ 은 $350 \mathrm{mV}$ 이 고, 단락회로전류 $\left(\mathrm{ISC}_{\mathrm{SC}}\right)$ 는 $147 \mathrm{uA}$ 이며, $\mathrm{MPP}$ 에서의 전압 $\left(\mathrm{V}_{\mathrm{MPP}}\right)$ 은 $266 \mathrm{mV}$ 이다. 일반적으로 $\mathrm{PV}$ 셀의 출력동작 전압 $\left(\mathrm{V}_{\mathrm{OP}}\right)$ 은 아래 식으로 정의될 수 있다.

$$
V_{O P} \cong K_{O P} \cdot V_{O C}
$$

$\mathrm{MPP}$ 조건에서는 비례상수 $\mathrm{K}_{\mathrm{OP}}$ 와 $\mathrm{V}_{\mathrm{OP}}$ 는 각각 $\mathrm{K}_{\mathrm{MPP}}$ 와 $\mathrm{V}_{\mathrm{MPP}}$ 로 표시할 수 있다.

$$
V_{M P P} \cong K_{M P P} \cdot V_{O C}
$$

보통의 경우 $\mathrm{K}_{\mathrm{MPP}}$ 는 0.6 에서 0.8 사이의 값을 갖는다 [4 6]. 본 설계에서 사용된 소자의 $\mathrm{K}_{\mathrm{MPP}}$ 측정값은 0.75 이다.

\section{Voltage booster (VB)}

그림 4의 $\mathrm{VB}$ (voltage booster)는 주 $\mathrm{PV}$ 셀에서 출력 되는 $0.5 \mathrm{~V}$ 이하의 전압 $\left(\mathrm{V}_{\mathrm{SC}}\right)$ 을 $\mathrm{SEMC}$ 가 동작하는데 필 요한 $1 \mathrm{~V}$ 의 이상의 전압 $\left(\mathrm{V}_{\mathrm{CP}}\right)$ 으로 승압하는 역할을 한 다. $\mathrm{VB}$ 는 링 발진기와 전하펌프로 구성되어 있다.

링 발진기는 3 단으로 구성하였으며, 전하펌프는 간단

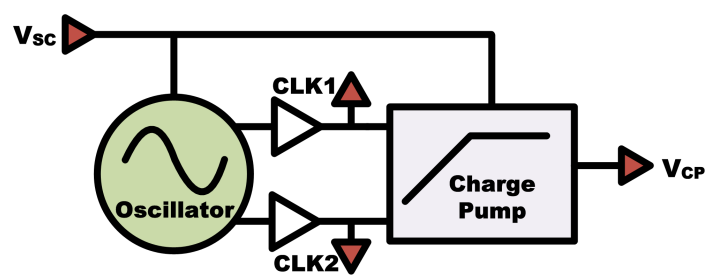

그림 4. Voltage booster 블록도

Fig. 4. Block diagram of voltage booster. 
한 Dickson 구조를 사용하였다. 전하펌프의 단수는 8이 며, 각 단에 사용된 커패시터의 값은 $10 \mathrm{pF}$ 이다. 다이오 드로 사용된 $\mathrm{nMOS}$ 트랜지스터는 뒷단으로 갈수록 body effect의 영향으로 문턱전압이 증가하게 된다. 따 라서 작은 입력전압으로부터 전하펌핑 능력을 증가시키 기 위해 본 설계에서는 사용된 공정에서 제공하는 native nMOSFET 소자를 이용하여 전하펌프를 구현하 였다.

\section{SEMC(Solar Energy MPPT Control)}

그림 5는 본 논문에서 제안된 MPPT 기능을 수행하 는 $\mathrm{SEMC}$ 의 블록도이다. SEMC 회로는 파일럿 $\mathrm{PV}$ 셀, 저항 분주기, 비교기, 그리고 래치로 구성된다. 파일럿 $\mathrm{PV}$ 셀은 출력에 연결된 저항 분주기를 통해 $\mathrm{MPP}$ 전 압에 해당하는 기준전압 $\left(\mathrm{V}_{\mathrm{MPP}, \max }, \mathrm{V}_{\mathrm{MPP}, \min }\right)$ 을 비교기에 공급하는 역할을 한다. 두 개의 비교기는 파일럿 $\mathrm{PV}$ 셀에서 공급된 기준전압을 주 $\mathrm{PV}$ 셀의 출력인 $\mathrm{Vsc}$ 와 비교하여 $\mathrm{Vsc}_{\mathrm{sc}} \mathrm{V}_{\mathrm{MPP} \text { max }}$ 또는 $\mathrm{V}_{\mathrm{MPP} \text { min }}$ 에 도달했는지 를 감지한다. 비교기가 감지한 신호를 기반으로 래치는 'EN' 신호 $\left(\mathrm{V}_{\mathrm{EN}}\right)$ 를 발생시켜서, 부하에 전력을 공급하기 위한 전력 스위치(그림 1 참조)의 on/off 상태를 결정 하게 된다.
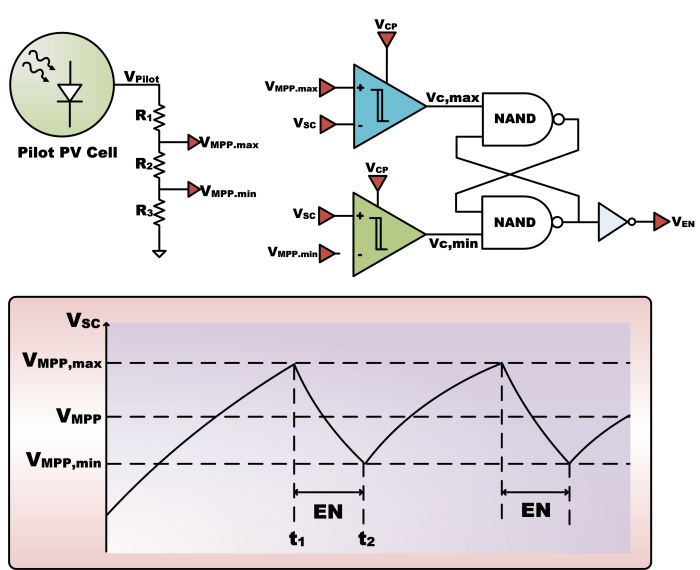

그림 5. SEMC 블록도 및 동작원리

Fig. 5. Block diagram of SEMC and its operational principles.

$\mathrm{SEMC}$ 의 MPPT 제어 동작원리는 다음과 같다.

(1) 먼저 시스템이 빛에너지를 받게 되면 주 PV 셀의 출력 커패시터 $\mathrm{Csc}$ 가 충전되어 출력전압 $\mathrm{Vsc}$ 가 증가한다. (충전 단계)

(2) $\mathrm{V}_{\mathrm{SC}}$ 가 미리 설정된 $\mathrm{MPP}$ 전압 상한 값 $\left(\mathrm{V}_{\mathrm{MPP} \text { max }}\right)$ 에 도달하면 $\left(\mathrm{t}=\mathrm{t}_{1}\right), \mathrm{SEMC}$ 가 ' $\mathrm{EN}^{\prime}$ 신호를 발생시
켜서 전력 스위치를 'on'시키고 부하에 전력을 공 급하게 된다.

(3) 보통의 경우 PV 셀에서 발생되는 전력은 부하에 서 소모되는 전력 보다 작기 때문에, 전력 스위치 가 'on'되어 있는 동안에는 $\mathrm{V}_{\mathrm{SC}}$ 가 감소하게 된다. (방전 단계)

(4) $\mathrm{V}_{\mathrm{SC}}$ 가 미리 설정된 $\mathrm{MPP}$ 전압 하한 값 $\left(\mathrm{V}_{\mathrm{MPP}, \min }\right)$ 까지 감소하게 되면 $\left(\mathrm{t}=\mathrm{t}_{2}\right), \mathrm{SEMC}$ 가 전력 스위치 를 'off'시키고 부하에 전력 공급을 차단하게 되어 $\mathrm{V}_{\mathrm{SC}}$ 는 다시 증가하게 된다.

(5) 이와 같은 충/방전 과정은 계속 반복되고 주 $\mathrm{PV}$ 셀은 항상 기 설정된 $\mathrm{MPP}$ 범위 $\left(\mathrm{V}_{\mathrm{MPP}, \min }\right.$ $\mathrm{V}_{\mathrm{MPP} \text { max }}$ )에서 동작하게 된다.

본 설계에서는 파일럿 $\mathrm{PV}$ 셀을 이용하여 주 $\mathrm{PV}$ 셀 의 $\mathrm{MPP}$ 를 실시간 추적할 수 있도록 하였다. 파일럿 $\mathrm{PV}$ 셀은 주 $\mathrm{PV}$ 셀보다 면적은 작지만 같은 소자이고, 같은 환경에서 같은 빛의 세기를 받게 되기 때문에 두 셀의 $\mathrm{MPP}$ 는 일치한다고 가정할 수 있다. $\mathrm{PV}$ 셀의 $\mathrm{MPP}$ 전압 $\mathrm{V}_{\mathrm{MPP}}$ 와 개방회로 전압 $\mathrm{V}_{\mathrm{OC}}$ 는 식 (2)의 비례 관계가 성립한다. 또한, 참고문헌 [1]에 따르면 비례상 수 $\mathrm{K}_{\mathrm{MPP}}$ 는 빛의 세기에 따라 변하지만, $\mathrm{K}_{\mathrm{MPP}}$ 가 고정됐 다고 가정해도 $\mathrm{V}_{\mathrm{MPP}}$ 예측의 오차는 $5 \%$ 이내 임을 측정 결과로 보여주었다. 따라서 본 설계에서는 $\mathrm{PV}$ 셀의 측 정된 데이터 $\left(\mathrm{V}_{\mathrm{OC}}=350 \mathrm{mV}, \mathrm{V}_{\mathrm{MPP}}=266 \mathrm{mV} @ 10 \mathrm{klux}\right)$ 를 이 용하여, $\mathrm{K}_{\mathrm{MPP}}$ 값을 0.75 로 설정하였다.

$\mathrm{MPP}$ 동작범위를 결정하는 기준전압 $\mathrm{V}_{\mathrm{MPP}, \max }$ 와 $\mathrm{V}_{\mathrm{MPP}, \min }$ 은 $\mathrm{V}_{\mathrm{MPP}}$ 에서 오차가 $\pm 10 \%$ 이내가 되도록, 파일 럿 PV 셀의 출력에 연결되어 있는 저항 분주기의 저항 값을 설정하였다. 저항 분주기에 사용된 저항 값의 합 은 $2 \mathrm{M} \Omega$ 으로 비교적 큰 값을 사용하였다. 따라서 기준 전압 $\mathrm{V}_{\mathrm{MPP}, \max }$ 와 $\mathrm{V}_{\mathrm{MPP}, \min }$ 은 파일럿 $\mathrm{PV}$ 셀의 개방회로 전압에 비례하는 값이 된다.

\section{IC 제작 및 측정 결과}

설계된 마이크로 빛에너지 하베스팅 회로는 $0.18 \mu \mathrm{m}$ $\mathrm{CMOS}$ 공정으로 제작 되었다. 그림 6 은 설계된 회로의 칩 사진이며, 면적은 패드를 포함하여 $1370 \mathrm{um} \times 900 \mathrm{um}$ 이다. 그림 7은 제작된 칩의 성능을 검증하기 위해 제작한 $\mathrm{PCB}$ 보드와 측정환경 사진이다. 주 $\mathrm{PV}$ 셀과 파일럿 $\mathrm{PV}$ 셀은 2장에서 소개한 'SCPD' 소 자를 이용하였으며, 조명등을 사용하여 빛을 공급 


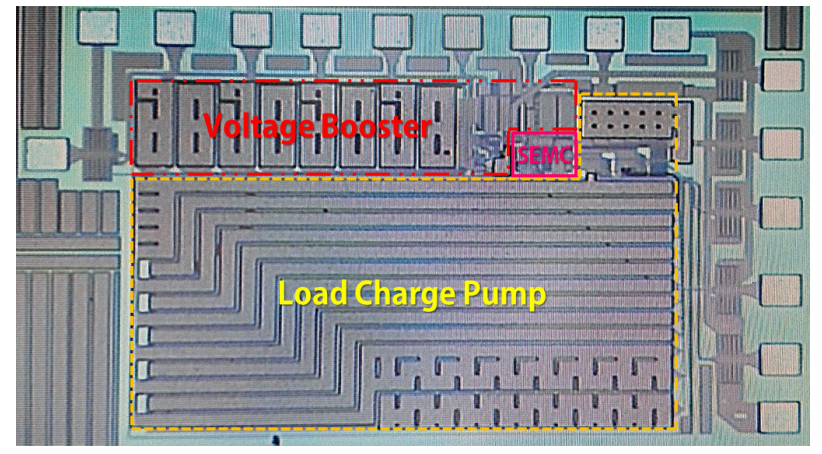

그림 6. 제작된 빛에너지 하베스팅 회로 칩 사진

Fig. 6. Chip photograph of the designed micro solar energy harvesting circuit.

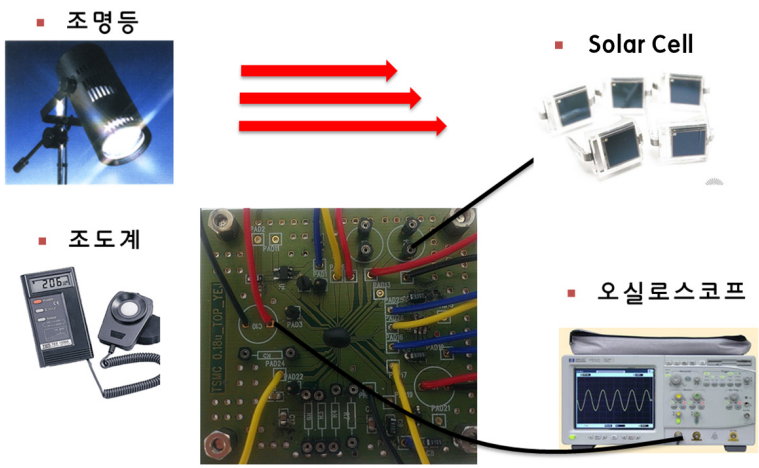

그림 7. 테스트 보드 및 측정환경

Fig. 7. Test board and measurement setup.

하였다. 빛의 세기는 조도계를 이용하여 측정하였 으며, 조명등의 거리를 조절하여 원하는 조도를 맞추었다.

그림 8은 제작된 빛에너지 하베스팅 회로를 10klux의 조도에서 측정한 결과이다. 그림 8의 (a)는 부하단 $\left(\mathrm{V}_{\mathrm{Load}}\right)$ 에 부하 전하펌프 대신 $650 \Omega$ 의 저항이 연결되었 을 때의 측정 파형이다. 측정결과 $\mathrm{V}_{\mathrm{MPP}, \max }$ 는 $292 \mathrm{mV}$ 이 고, $\mathrm{V}_{\mathrm{MPP}, \min }$ 은 $236 \mathrm{mV}$ 이다. 따라서, 주 $\mathrm{PV}$ 셀의 출력 $\mathrm{V}_{\mathrm{SC}}$ 가 $\mathrm{V}_{\mathrm{MPP}}(266 \mathrm{mV})$ 의 $\pm 11 \%$ 이내에서 $\mathrm{MPPT}$ 제어되 는 것을 확인할 수 있다. 방전 단계(전력 스위치가 on 되었을 때)에서는 주 PV 셀로부터 수확된 전력이 부하 저항으로 공급되는 것을 $\mathrm{V}_{\mathrm{Load}}$ 파형에서 확인할 수 있 다. 그림 8 의 $(\mathrm{b})$ 는 부하단 $\left(\mathrm{V}_{\mathrm{Load}}\right)$ 에 부하 전하펌프가 연결되었을 때의 측정 파형이다. 부하 전하펌프의 링 발진기가 부하에 전력이 공급되는 방전 단계에서만 동 작하는 것을 확인할 수 있다. 링 발진기에서 출력되는 클럭의 초기 주파수는 $1.37 \mathrm{MHz}$ 이다.

그림 9는 $10 \mathrm{klux}$ 의 빛 세기에서 부하 저항 변화에 따 른 $\mathrm{V}_{\mathrm{SC}}$ 와 $\mathrm{V}_{\mathrm{Load}}$ 파형이다. 부하저항이 $440 \Omega$ 과 $2.1 \mathrm{k} \Omega$ 일 때 듀티 싸이클은 각각 $13.7 \%$ 와 $79.3 \%$ 이다. 부하저항이

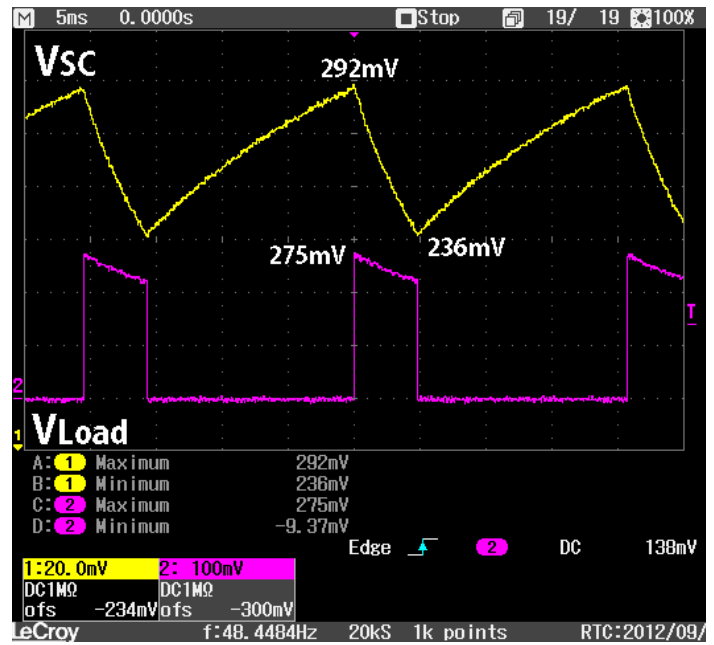

(a)

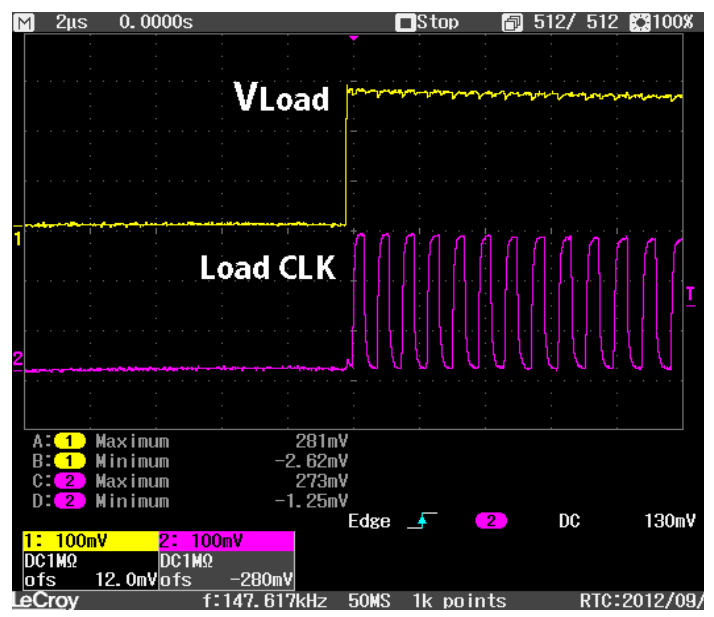

(b)

그림 8. 제작된 빛에너지 하베스팅 회로의 측정 파형 (a) VSC 와 VLoad (b) VLoad와 부하단 전하펌 프 클럭

Fig. 8. Experimental responses (a) VSC and VLoad (b) VLoad and load charge pump clock.

증가하면 부하에서 소모되는 전력이 감소하기 때문에 듀티 싸이클은 증가하게 된다. 측정결과 부하저항이 $2.2 \mathrm{k} \Omega$ 일 때 듀티 싸이클은 $100 \%$ 가 된다.

그림 10 은 빛의 세기가 $6.7 \mathrm{klux}$ 에서 $4.2 \mathrm{klux}$ 로 감소했 을 때, $\mathrm{V}_{\mathrm{SC}}$ 의 파형 변화를 측정한 결과이다. 빛의 세기 가 감소하면 $\mathrm{PV}$ 셀의 개방회로 전압 $\left(\mathrm{V}_{\mathrm{OC}}\right)$ 도 감소한다. 따라서, $\mathrm{MPP}$ 전압 $\left(\mathrm{V}_{\mathrm{MPP}}\right)$ 도 감소하며, 이에 비례하여 $\mathrm{MPP}$ 기준전압인 $\mathrm{V}_{\mathrm{MPP}, \max }$ 와 $\mathrm{V}_{\mathrm{MPP}, \min }$ 도 함께 감소하게 된다. 이 측정결과로부터 설계된 회로는 빛의 세기 변 화에 따른 $\mathrm{MPP}$ 전압 변화를 실시간 추적하고 있음을 확인할 수 있다.

그림 11 은 빛의 세기에 따른 $\mathrm{K}_{\mathrm{OP}}$ 변화를 측정한 결 과이다. $\mathrm{MPPT}$ 제어를 적용한 경우, 측정된 $\mathrm{K}_{\mathrm{OP}}$ 값의 


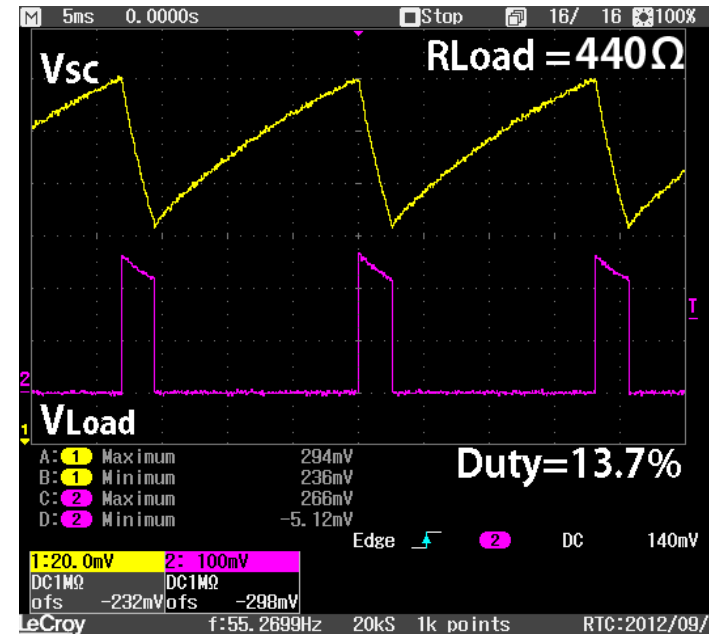

(a)

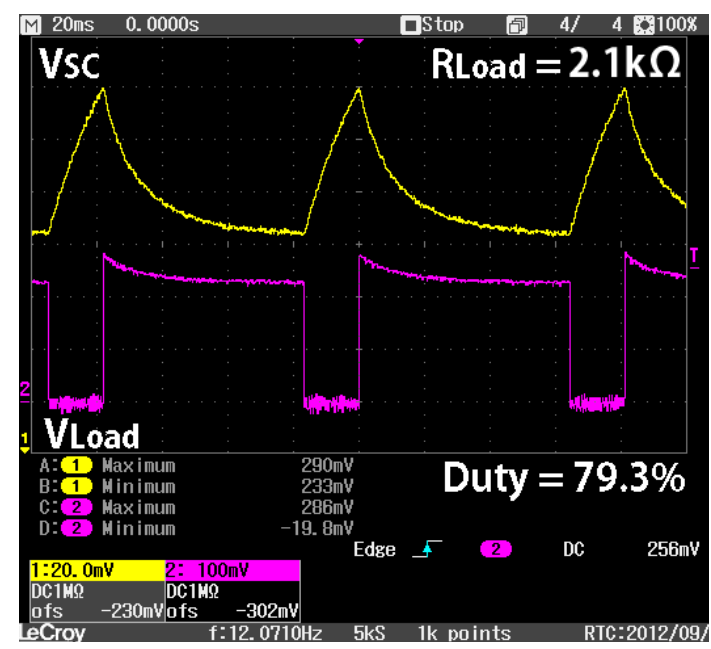

(b)

그림 9. 부하저항에 따른 듀티 싸이클 측정결과

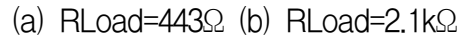

Fig. 9. Measured duty cycles at different load

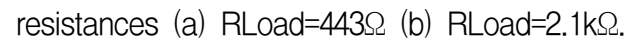

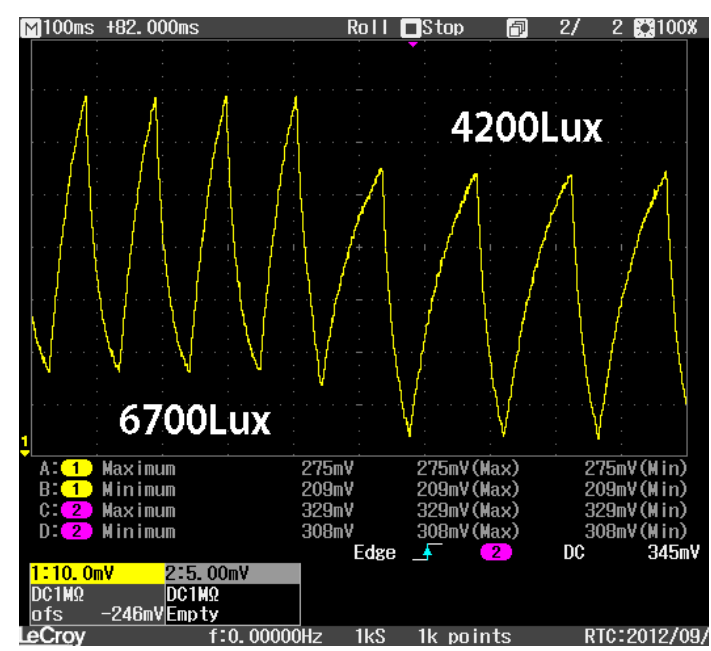

그림 10. 빛의 세기 변화에 따른 MPPT 제어 과정

Fig. 10. MPPT control process with the variation of light intensity.
범위는 $0.7 \sim 0.8$ 이며, 이는 $\mathrm{K}_{\mathrm{MPP}}$ 가 0.75 이므로 $\mathrm{MPP}$ 전 압 범위 안에 포함된다. 따라서 설계된 회로는 다양한 빛의 세기에서 $\mathrm{MPP}$ 범위내의 전력을 부하로 공급하는 것을 알 수 있다. $\mathrm{MPPT}$ 제어를 적용하지 않은 경우에 는 측정된 $\mathrm{K}_{\mathrm{OP}}$ 값의 범위는 $0.5 \sim 0.75$ 이다. 이는 빛의 세기 범위의 상당부분(특히 낮은 빛의 세기)에서 $\mathrm{MPP}$ 범위를 벗어나는 것을 알 수 있다.

그림 12 는 부하 저항에 따른 주 $\mathrm{PV}$ 셀의 출력 동작 전압 $\left(\mathrm{V}_{\mathrm{OP}}\right)$ 을 측정한 결과이다. $\mathrm{MPPT}$ 제어를 적용한 경우에 측정된 $\mathrm{V}_{\mathrm{OP}}$ 값의 범위는 $240 \mathrm{mV} \sim 260 \mathrm{mV}$ 로 안 정적인 특성을 보인다. 특히, 듀티 싸이클이 $100 \%$ 가 되 는 부하저항 값인 $2.2 \mathrm{k} \Omega$ 보다 작은 부하저항 범위에서는 $\mathrm{V}_{\mathrm{OP}}$ 값이 $260 \mathrm{mV}$ 로 거의 일정한 특성을 보인다. $\mathrm{MPPT}$ 제어를 적용하지 않은 경우에는 부하에 따라 $\mathrm{V}_{\mathrm{OP}}$ 값의 변화가 $0 \sim 250 \mathrm{mV}$ 로 매우 크다. 특히, 부하저항이 작을 때(부하가 클 때) $\mathrm{V}_{\mathrm{OP}}$ 값은 매우 작아지며, 따라서 부하 단 구동이 더욱 어려워진다.

부하저항 변화에 따른 부하에 공급되는 전력을 그림 13 에 보였다. MPPT 제어를 적용한 경우가 적용하지 않은 경우에 비해 더 많은 전력이 부하에 공급되는 것 을 확인할 수 있다. 특히, 부하저항이 작은 경우 $\mathrm{MPPT}$ 제어의 효과가 더 큰 것을 알 수 있다. 측정된 최대 부 하 전력은 $2.1 \mathrm{k} \Omega$ 부하에서 $25.7 \mathrm{uW}$ 이다. 그림 14 는 $\mathrm{MPPT}$ 제어를 적용한 경우의 전력효율 그래프이다. 전 력효율은 부하에 전달된 전력과 주 $\mathrm{PV}$ 셀의 최대가용 전력의 비로 계산하였다. 측정된 전력효율의 최대 값은 $78 \%$ 이다. MPPT 동작이 이루어지는 범위 (즉 듀티 싸 이클이 $100 \%$ 미만인 경우)에서 부하저항이 작아질수록 (즉 부하가 커질수록) 부하에 공급되는 전력이 다소 감 소하며, 따라서 전력효율도 감소한다. 이는 부하저항이

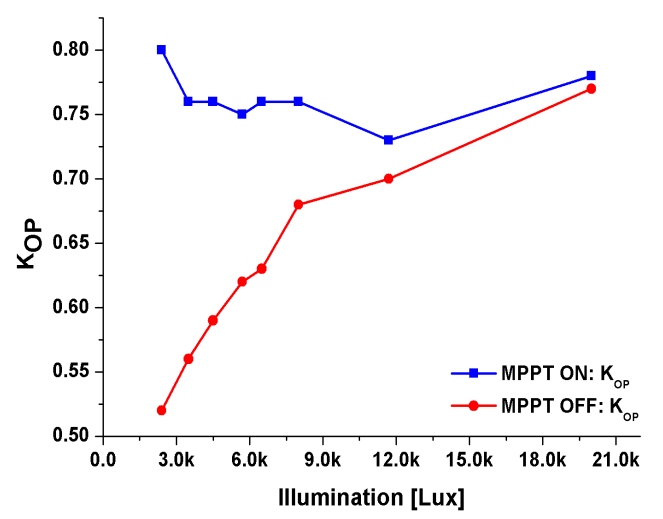

그림 11. 빛의 세기에 따른 $\mathrm{KOP}$ 변화

Fig. 11. KOP versus light intensity. 


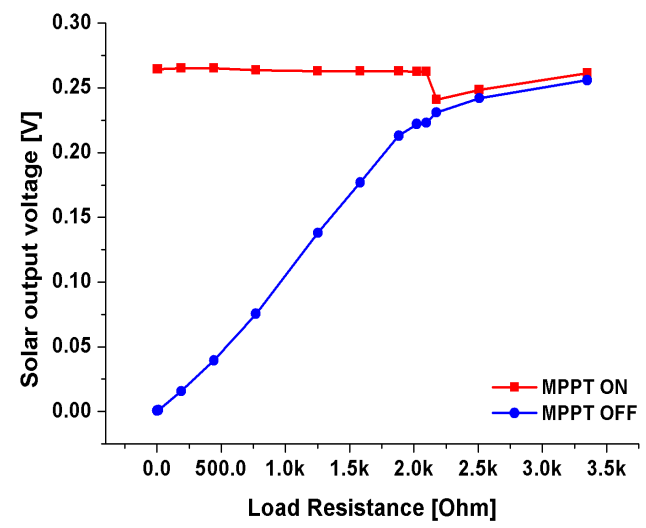

그림 12. 부하 저항에 따른 $\mathrm{PV}$ 셀의 동작전압 (VOP)

Fig. 12. VOP versus load resistances.

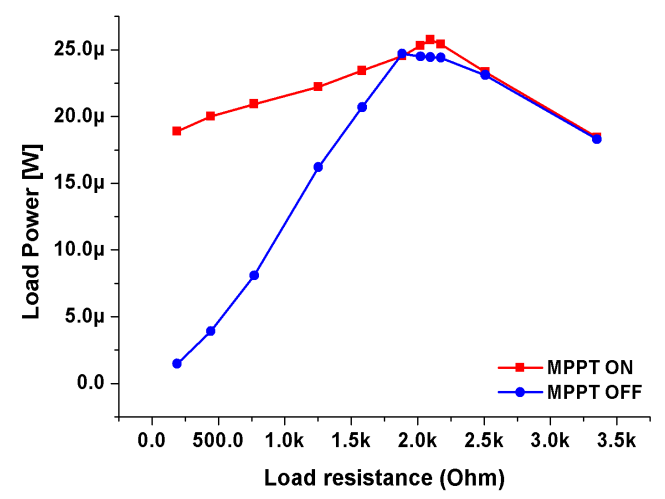

그림 13. 부하저항에 따른 부하 전력

Fig. 13. Load power versus load resistances.

작아질수록 전력스위치의 on 저항이 상대적으로 커져 서 전력스위치에서의 전압 강하가 커지기 때문이다. 이 문제를 개선하기 위해서는 전력스위치의 크기를 키워서 on 저항을 더욱 줄일 필요가 있다.

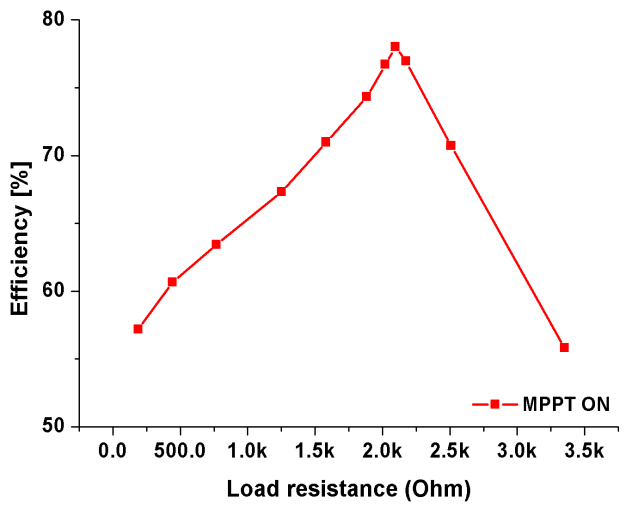

그림 14. MPPT가 적용 되었을 때의 전력 효율 Fig. 14. Power efficiency when MPPT is on.

표 1에 최근에 발표된 마이크로 빛에너지 하베스팅 시스템들과 본 논문에서 제안된 회로를 비교하였다. 참 고문헌 [7]과 [8]에서 제안된 방법은 제어회로 시동을 위해 미리 충전된 배터리가 필요하기 때문에 배터리를 사용하지 않는 자가발전 시스템에는 적합하지 않다. 참 고문헌 [6]에서는 $\mathrm{ISC}$ 를 사용하여 $\mathrm{FOC}$ 방법을 구현하 였으나 제어회로 구동을 위해 $\mathrm{p}-\mathrm{diff} / \mathrm{n}$-well 다이오드의 직렬연결을 사용하였기 때문에 기생다이오드에서 발생 하는 누설전류가 문제가 될 수 있다. 또한 이들 방법들 은 칩 구현 결과는 없으며, 모의실험 결과만 제시하고 있다. 제안된 회로는 제어회로 구동을 위해 미리 충전 된 배터리가 필요하지 않기 때문에 배터리를 사용하지 않는 초소형 자가발전 시스템에 적합하다.

표 1. 마이크로 빛에너지 하베스팅 시스템 비교

Table 1. Comparison of micro-scale solar energy harvesting systems.

\begin{tabular}{|c|c|c|c|c|}
\hline & {$[6]$} & {$[7]$} & {$[8]$} & This work \\
\hline $\begin{array}{c}\text { PV cell type } \\
\text { (Size) }\end{array}$ & $\begin{array}{c}\text { ISC } \\
\text { (N/A) }\end{array}$ & $\begin{array}{c}\text { single cell } \\
\left(0.64 \mathrm{~cm}^{2}\right)\end{array}$ & $\begin{array}{c}\text { two single cells } \\
\text { in series }\left(20.2 \mathrm{~cm}^{2}\right)\end{array}$ & $\begin{array}{c}\text { single cell } \\
\left(0.14 \mathrm{~cm}^{2}\right)\end{array}$ \\
\hline $\begin{array}{c}\text { PV cell open voltage } \\
\text { Voc (V) }\end{array}$ & $<0.5$ & $<0.5$ & $<1.1$ & $<0.5$ \\
\hline MPPT Scheme & FOC & $\begin{array}{c}\text { Negative-feedback } \\
\text { automatic tracking }\end{array}$ & Hill climbing & $\begin{array}{c}\text { FOC \& } \\
\text { pilot cell }\left(0.07 \mathrm{~cm}^{2}\right)\end{array}$ \\
\hline $\begin{array}{c}\text { Controller power } \\
\text { source }\end{array}$ & $\begin{array}{c}\text { Auxiliary } 4 \text { diodes } \\
\text { in series (1.6V) }\end{array}$ & $\begin{array}{c}\text { Rechargeable battery } \\
(0.9 \mathrm{~V})\end{array}$ & $\begin{array}{c}\text { Rechargeable battery } \\
(1 \mathrm{~V})\end{array}$ & $\begin{array}{c}\text { Main PV cell } \\
(<0.5 \mathrm{~V})\end{array}$ \\
\hline $\begin{array}{c}\text { Max. } \\
\text { Efficiency(\%) }\end{array}$ & N/A & 39.5 & 90 & $\begin{array}{c}78 \\
\text { charge pump) }\end{array}$ \\
\hline Verification & Simulation & Simulation & Simulation & Measurement \\
\hline Process(nm) & 500 & 45 & 65 & 180 \\
\hline Year & 2010 & 2012 & 2012 & 2013 \\
\hline
\end{tabular}




\section{$\mathrm{V}$. 결 론}

본 논문에서는 센서노드와 같은 초소형 자가발전 시 스템을 위한 마이크로 빛에너지 하베스팅 시스템을 제 안하였다. FOC 방법을 이용하여 MPPT 제어 기능을 구현하였으며, 파일럿 PV 셀을 이용하여 주 PV 셀의 개방회로 전압을 간단히 예측하였다. $\mathrm{MPPT}$ 제어회로 의 구동은 간단한 승압회로를 사용하여 주 PV 셀의 출 력 전압을 승합하여 사용하기 때문에 미리 충전된 배터 리는 필요하지 않다. 제안된 회로는 0.18um CMOS 공 정으로 설계되었으며, 칩 면적은 부하단 전하펌프와 패 드를 포함하여 $900 \mathrm{um} \times 1370 \mathrm{um}$ 이다. 제작된 칩을 측정 한 결과 설계된 회로는 빛 세기의 변화에 따른 $\mathrm{MPP}$ 전 압 변화를 실시간 트래킹한다. 기존의 마이크로 빛에너 지 하베스팅 회로에 비해 제안된 회로는 제어회로 구동 을 위해 미리 충전된 배터리가 필요하지 않기 때문에 배터리를 사용하지 않는 초소형 자가발전 시스템에 적 합하다. 본 논문에서 설계된 마이크로 빛에너지 하베스 팅 회로는 매우 작은 크기로 구현가능하기 때문에 듀티 싸이클이 비교적 낮은 환경 모니터링 분야의 자가발전 센서노드에 활용될 수 있다.

\section{REFERENCES}

[1] D. Dondi, A. Bertacchini, L. Larcher, P. Pavan, D. Brunelli, and L. Benini, "A solar energy harvesting circuit for low power applications," IEEE ICSET, pp. 945-949, 2008.

[2] H. Shao, C. Tsui, and W. Ki, "The Design of a Micro Power Management System for Applications Using Photovoltaic Cells With the Maximum Output Power Control," IEEE Trans. on VLSI Systems, vol.17, no.8, pp. 1138-1142, 2009.

[3] I. Doms, P. Merken, C. Van Hoof, and R. P. Mertens, "Capacitive Power Management Circuit for Micropower Thermoelectric Generators With a 1.4 uA Controller," IEEE JSSC, vol. 44 , no. 10, pp. 2824-2833, 2009.

[4] C. Lu, V. Raghunathan, and K. Roy, "Maximum Power Point Considerations in Micro-Scale Solar Energy Harvesting Systems," ISCAS, pp. 273-276, 2010.

[5] D. Dondi, A. Bertacchini, D. Brunelli, L. Larcher, and L. Benini, "Modeling and optimization of a solar energy harvester system for self-powered wireless sensor networks," IEEE Trans. on
Industrial Electronics, pp. 2759-2766, 2008.

[6] E. Méndez-Delgado, G. Serranoy and E. I. Ortiz-Rivera, "Monolithic integrated solar energy harvesting system," 35th IEEE PVSC, pp. 2833-2838, 2010.

[7] C. Lu, S. P. Park, V. Raghunathan, and K. Roy, "Low-Overhead Maximum Power Point Tracking for Micro-Scale Solar Energy Harvesting Systems," VLSID, pp.215-220, 2012

[8] X. Li, C.-Y. Tsui, W.-H. Ki, "Solar Energy Harvesting System Design Using Re-configurable Charge Pump", IEEE FTFC, 2012.

[9] C. Hua et al., "Implementation of a DSP-controlled photovoltaic system with peak power tracking," IEEE Trans. on Industrial Electronics, vol. 45, pp. 99-107, Feb. 1998.

[10] W. Wu et al., "DSP-Based multiple peak power tracking for expandable power system," in Proc. Applied Power Electronics Conf. and Exposition 2003, vol. 1, pp. 525-530, 2003.

[11] C. Hua and C. Shen, "Control of DC/DC converters for solar energy system with maximum power tracking," 23rd IECON, vol.2, pp. 827-832, 1997.

[12] http://www.solarbotics.com 
저 자 소 개

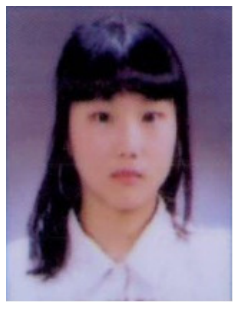

윤 은 정(학생회원)

2011년 인천대학교 전자공학과 학사 졸업.

2013년 인천대학교 전자공학과 석사 졸업.

2013년 2월 인천대학교 전자공 학과 박사과정

<주관심분야 : CMOS Analog/Mixed-mode IC 설계, 에너지 하베스팅 회로 설계>

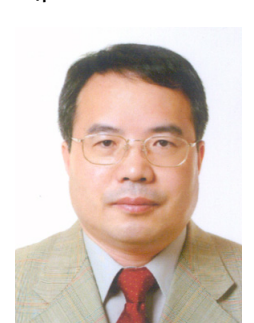

박 종 태(평생회원)

1981년 경북대학교 전자공학과 학사 졸업.

1983년 연세대학교 전자공학과 석사 졸업.

1987년 연세대학교 전자공학과 박사 졸업.

1991년 1월 1991년 12월 MIT Port Doc.

2000년 7월 2001년 8월 UC Davis 방문교수 1987년 3월 현재 인천대학교 전자공학과 교수 <주관심분야 : CMOS Reliability, Nano-scale CMOS, SOI/MOSFET, RF-CMOS

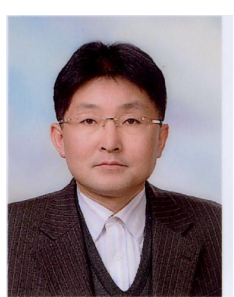

유 종 근(평생회원)

1985년 연세대학교 전자공학과 학사 졸업.

1993년 연세 대학교 전자공학과 석사 졸업.

1993년 Iowa State University 전기 및 컴퓨터공학과 박사 졸업.

2009년 8월 2010년 7월 UC Davis 방문교수 1994년 3월 현재 인천대학교 전자공학과 교수 <주관심분야 : CMOS Analog/Mixed-mode IC 설계, $\mathrm{RFIC}$ 설계> 